\title{
PENGARUH KEPEMIMPINAN DAN BUDAYA ORGANISASI TERHADAP PENGEMBANGAN USAHA BERBASIS SYARIAH DI KALANGAN WASHLIYIN PROVINSI SUMATERA UTARA
}

\author{
Burhanuddin \\ Sekolah Tinggi Ilmu Ekonomi Nusa Bangsa Sumatera Utara \\ b.naimbtr@gmail.com
}

\begin{abstract}
Al Jam'iyatul Washliyah organization abbreviated Al-Washliyah (AW) was established in Medan on November 30, 1930 to coincide with the 9th of Rajab 1349 H. A name of the largest Islamic community organization in North Sumatera Province, and the third largest in Indonesia after NU and Muhammadiyah.Although Al-Washliyah has businesses, it cannot yet be economically independent. This study tries to explain by looking for information on how the influence of leadership and organizational culture on the development of sharia-based enterprises in Washliyin North Sumatera Province. The research method used is qualitative research methods, while the data collection techniques used are field research which includes observation and interviews, as well as literature. The results of this study indicate that on the one hand leadership has a positive effect on the development of sharia-based businesses in Washliyin North Sumatra Province, for example, has been able to make new innovations by establishing Islamic banks PT. BPR Syariah Al-Washliyah that has never existed before. On the other hand there are still weaknesses in leadership, have not been able to enforce regulations according to demands, as a result the efforts have not been fully ordered by the organization and orderly administration. For example, there are businesses that don't work and eventually close, namely the AlWashliyah hospital / clinic in 2004. Then there has been a shift in the value of organizational culture, the decline of the ulama tradition in Washliyin circles, and the entry of the Al-Washliyah leadership elite from politicians.This also affected the development of sharia-based businesses in Washliyin, North Sumatra Province.
\end{abstract}

Keywords: Leadership, Organizational Culture, Sharia-Based Business Development.

\section{Organisasi Al Jam'iyatul Washliyah disingkat Al-Washliyah (AW)} didirikan di Medan pada tanggal 30 November 1930 bertepatan dengan tanggal 9 Rajab 1349 H.Suatu nama organisasi kemasyarakatan Islam terbesar di Provinsi Sumatera Utara, dan terbesar ketiga di Indonesia setelah NU dan Muhammadiyah. Meskipun Al-Washliyah memiliki usaha-usaha, namun belum dapat mandiri secara ekonomi. Penelitian ini mencoba menjelaskan dengan mencari informasi bagaimana pengaruh kepemimpinan dan budaya organisasi terhadap pengembangan usaha berbasis syariah di kalangan Washliyin Provinsi Sumatera Utara.Metode penelitian yang digunakan adalah dengan metode penelitian kualitatif, sedangkan teknik pengumpulan data yang digunakan adalah penelitian lapangan yang meliputi observasi dan wawancara, serta kepustakaan. Hasil penelitian ini menunjukkan, bahwa di satu sisi kepemimpinan berpengaruh positif terhadap pengembangan usaha berbasis syariah di kalangan Washliyin Provinsi 
324 AT-TAWASSUTH: Jurnal Ekonomi Islam, Volume IV No. 2 Juli -

Desember 2019: 323 - 348

Sumatera Utara, misalnya pasca PB AW pindah ke Jakarta telah mampu melakukan inovasi baru dengan mendirikan bank syariah PT. BPR Syariah AlWashliyah yang belum pernah ada sebelumnya. Di sisi lain masih terdapat kelemahan kepemimpinan, belum mampu menegakkan regulasi sesuai tuntutan, akibatnya usaha-usaha belum sepenuhnya tertib organisasi dan tertib administrasi. Misalnya terdapat usaha yang tidakjalan dan akhirnya tutup, yaitu rumah sakit/klinik Al-Washliyah pada tahun 2004.Kemudian telah tejadi pergeseran nilai budaya organisasi, kemunduran tradisi keulamaan di kalangan Washliyin, dan masuknya dalam struktur elit kepemimpinan Al-Washliyah dari oknum politisi.Hal ini turut mempengaruhi pengembangan usaha berbasis syariah di kalangan Washliyin Provinsi Sumatera Utara tersebut.

Kata Kunci: Kepemimpinan, Budaya Organisasi, Pengembangan Usaha Berbasis Syariah.

\section{Pendahuluan.}

Fenomena organisasi-organisasi kemasyarakatan (ormas) Islam yang tumbuh berkembang dari waktu ke waktu pada umumnya masih belum mampu mandiri secara ekonomi.Salah satu dari ormas Islam dimaksud adalah Al-Jam'iyatul Washliyah. Al-Washliyah merupakan organisasi kemasyarakata Islam terbesar di Provinsi Sumatera Utara, ${ }^{1}$ dan terbesar ketiga di Indonesia setelah NU dan Muhammadiyah. Kiprah dan eksistensi NU, Muhammadiyah, dan Al-Washliyah sebagai ormas terbesar di Indonesia memang sudah tidak diragukan lagi.Melalui berbagai amal usahanya, misal di sektor pendidikan dan sosial (rumah sakit/klinik kesehatan dan panti asuhan) NU, Muhammadiyah, dan Al-Washliyah telah dapat meningkatkan peran strategisnya bagi peningkatan kesejahteraan umat.Namun dari segi ekonomi tidak bisa disangkal bahwa organisasi ini masih kurang optimal. $^{2}$

Kiprah dan eksistensi Al-Washliyah sebagai ormas Islam terbesar di Provinsi Sumatera Utara dan terbesar ketiga di Indonesia tersebut, dimana hal ini dapat dilihat melalui berbagai amal usaha Al-Washliyah Provinsi Sumatera Utara di bidang pendidikan, amal sosial, dan ekonomi, telah dapat meningkatkan peran strategisnya bagi peningkatan kesejahteraan umat. Dari ketiga bidang usaha tersebut, segi ekonomi tidak bisa disangkal bahwa peran Al-Washliyah masih kurang optimal.Paling tidak prinsip-prinsip ekonomi Islam yang dianjurkan ternyata belum bisa diimplementasikan dalam keseharian.

Bilamana Washliyun dapat mengimplementasikan usaha berbasis syariah tersebut dengan baik, maka akan mendatangkan kesejahteraan bagi umat, 
khususnya bagi kalangan Washliyun Provinsi Sumatera Utara. Karena AlWashliyah merupakan ormas Islam terbesar di Sumatera Utara yang lahir di Medan ini sepatutnya akan mendatangkan manfaat bagi pengembangan usaha, untuk menjadi terbesar dari usaha ormas sejenisnya. Nyatanya tidak demikian.Padahal ditinjau dari segi kepengurusan Al-Washliyah dapat dijumpai di 27 kota/kabupaten Sumatera Utara dari 33 total jumlah kota/kabupten Sumatera Utara. Akan tetapi masih ada ormas lain sejenisnya di Sumatera Utara yang memiliki unit usaha yang lebih banyak unitnya dari pada yang dimiliki oleh AlWashliyah.

Dari sisi budaya organisasi, pada awal perkembangan Al-Washliyah hingga era 1980-an, para pengurus berjuang dalam kondisi sederhana sesuai situasi dan kondisi pada masa itu, dimana ada yang datang menghadiri rapat pengurus, maupun pada kegiatan organisasi mereka berjalan kaki, atau bersepeda, bahkan mengeluarkan biaya sendiri (peribadi). Keadaan ini ridak menghalangi mereka untuk terus mengembangkan usaha Al-Washliyah.Dan nyatanya organisasi dapat berjalan, khususnya bidang dakwah, pendidikan, dan sosial (panti-panti asuhan).

Kini, sedemikian banyak tokoh pengurus Al-Washliyah yang menduduki posisi pengusaha lokal dan regional, posisi birokrat, pengurus partai dan yang menjadi angota Dewan Perwakilan Rakyat (DPR/D).Keadaan ini menunjukkan bahwa mereka dapat hadir dalam rapat maupun kegiatan-kegiatan organisasi dengan mengenderai mobil, paling tidak sepeda motor (roda dua). Lalu, apa yang kurang? Kemampuan Al-Washliyah untuk melakukan terobosan mengembangkan usaha dalam bidang ekonomi, pendidikan dan, sosial masih terasa kurang. Hal ini disebabkan oleh adanya faktor-faktor yang mempengaruhi pengembangan usaha berbasis syariah tersebut.

Permasalahan turunan lainnya yang juga mempengaruhi kontribusi dan eksistensi lembaga masyarakat Islam dalam pengembangan usaha ekonomi berbasis syariah adalah tidak adanya penguatan pada aspek ideologi, organisasi, dan kaderisasi.Dalam konteks ideologi, prinsip Islam yang kurang dipahami dan tidak diimplementasikan secara käffah (total) justeru memberikan kesempatan kepada pemahaman baru untuk masuk ke masyarakat.Padahal pemahaman ini belum tentu sejalan dengan syariat dan nilai-nilai ekonomi Islam. Tidak jarang, kontra produktif implementasi ideologi baru muncul melalui pluralisme dan atas nama kepentingan umat. Penguatan ajaran dan ideologi Islam yang masih belum 
326 AT-TAWASSUTH: Jurnal Ekonomi Islam, Volume IV No. 2 Juli -

Desember 2019: 323 - 348

maksimal inilah yang menghambat laju individu umat Islam untuk maju, yang kemudian bermuara terhadap cerminan organisasi Islam.Karena organisasi Islam adalah cerminan nilai-nilai dan pemikiran masyarakat yang dilembagakan dalam bentuk pranata sosial dan ekonomi.

Oleh karena itu, ke depan Washliyun harus melakukan instrospeksi dan reorientasi agar bisa lebih mampu berkiprah lebih banyak lagi terutama terkait dengan peningkatan kesejahteraan umat. Salah satu persoalan mendasar tantangan bagi ormas Islam Al-Washliyah ke depan adalah orientasi untuk meningkatkan kesejahteraan umat. Meskipun harus diakui bahwa penanganan persoalan ini tidaklah mudah, karena banyak faktor yang dapat mempengaruhi pengembangan usaha berbasis syariah baik faktor internal maupun eksternal. Faktor-faktor internal meliputi: organisasi, administrasi, manajemen, kepemimpinan, motivasi ekonomi syariah, aset, budaya organisasi, minat, dan pemahaman.

Sedangkan faktor eksternal, yaitu bila dikaitkan dengan semakin kuatnya cengkeraman kapitalisme ${ }^{3}$ di semua sendi kehidupan.Akibat adanya faktor-faktor yang mempengaruhi usaha tersebut, ormas-ormas Islam, termasuk Al-Washliyah belum mampu mandiri secara ekonomi.Artinya oganisasi ini belum mampu mengembangkan usahanya secara mandiri, sehingga masih membutuhkan bantuan pihak lain, baik dari pemerintah, maupun swasta lainnya.Maka tidak heran jika ada ormasIslam di Indonesia, dalam kegiatannya adakalanya harus membuat proposal mohon bantuan kepada pihak-pihak tertentu meskipun bantuan yang besifat tidak mengikat guna kelancaran operasional organisasi.Keadaan semacam ini dapat memberikan celah bagi para politisi menarik omas tersebut kepada kegiatan mereka guna menyukseskan tujuan, seperti dalam urusan dukung mendukung salah satu partai politik baik dalam pemilihan legislatif (PILEG), maupun pemilihan presiden (PILPRES). Tentu akan berbeda keadaanya jika organisasi kemasyarakatan Islam, seperti Al-Washliyah dapat mandiri dalam keuangan, karena didukung oleh usaha-usaha yang dimiliki dapat berjalan dengan baik, sehingga tidak tergantung kepada pihak-pihak lain.

Dari sisi organisasi, kelemahan mendasar organisasi masyarakat Islam dewasa ini adalah tidak adanya pengelolaan organisasi yang profesional.Indikatorindikator keberhasilan organisasi yang tidak dibuat, visi dan misi organisasi yang tidak sesuai dengan perkembangan dinamika masyarakat dan masalah kekinian 
menjadi hambatan majunya organisasi masyarakat. Belum terkelolanya potensi ini tidak lain karena pengelolaan organisasi yang masih bersifat tradisional dan tidak efisien. Rekruetmen dan pengembangan keahlian nazhir (pengurus yang diamanahi suatu urusan) yang tidak merit system serta inkonsistensi managerial keahlian nazhir semakin memperlambat laju responsitas organisasi pengelola usaha untuk lebih produktif dan profesional.Tidak produktifnya usaha juga tidak lepas dari implementasi prinsip tata kelola yang baik (good governance) dalam setiap fase pengelolaan organisasi Islam.Rentang kendali organisasi dari pusat ke daerah juga menjadi kendala karena struktur organisasi yang cenderung tumpang tindih, tidak efisien dan tidak responsif dalam merespon permasalahan yang muncul.

Dari sisi administrasi, bahwa mustahil pada akal jika usaha-usaha organisasi Al-Washliyah ini dapat diselenggarakan dengan baik tanpa administrasi yang baik.Dengan kata lainbaik buruk usaha dapat dilihat salah satunya dari baiktidaknya penyelenggaraan administrasi itu sendiri.Dari sisi manajemen, bahwa tugas masing-masing pejabat baik yang membantu administrator maupun yang membantu manajer/ eksekutif, berbeda-beda satu sama yang lain sesuai dengan sasaran yang akan dicapai masing-masing. Dalam melaksanakan tugas, semua pejabat perlu bekerja sama yang mengarah kepada pencapaian tujuan pokok organisasi. Supaya semua kegiatan yang berbeda-beda namun menuju pencapaian tujuan akhir maka perlu ada yang mengarahkan dan yang menyelaraskan.Unsurunsur itu disebut unsur manajemen yang terkenal dengan $6 \mathrm{M}$ (man, money, material, machine, method, dan marketing).Demikian pentingnya peran manajemen yang dapat mempengaruhi dalam pengelolaan dan penataan usaha agar berfungsi sesuai fungsi masing-masing mencapai tujuan organisasi.

Dari sisi kepemimpinan sebagaimana dikemukakan oleh Sutarto, bahwa kepemimpinan adalah rangkaian kegiatan penataan berupa kemampuan mempengaruhi perilaku orang lain dalam situasi tertentu agar bersedia bekerja sama untuk mencapai tujuan yang telah ditetapkan. ${ }^{4}$ Aktivitas mempengaruhi orang-orang agar mau bekerja sama untuk mencapai beberapa tujuan yang mereka inginkan. Kepemimpinan diibaratkan sebagai sebuah alat atau sarana untuk mempengaruhi seorang atau sekelompok orang agar bersedia melakukan sesuatu secara sukarela seperti apa yang telah direncanakan di awal pemikiran seorang pemimpin itu sendiri. Seorang pemimpin akan dituntut secara terus menerus untuk 
328 AT-TAWASSUTH: Jurnal Ekonomi Islam, Volume IV No. 2 Juli -

Desember 2019: 323 - 348

memunculkan ide-ide kreatifnya agar usaha yang dijalankannya bisa meningkatkan performancenya dalam segala bidang dan bisa bertahan atau bisa beradaptasi dalam perubahan lingkungan. Ini menunjukkan bahwa sebuah kepemimpinan sangatlah penting untuk mendorong sebuah organisasi meraih tujuannya.Namun kepemimpinan dalam konteks idea penelitian ini penulis menyebutnya dengan kepemimpinan lillah (Lillah leadership and sharia entrepreneurship).Kepemimpinan yang profesional Islami, memiliki kecerdasan akal dan nurani, berorientasi dakwah lillāh warasūlihserta memiliki jiwa kewirausahaan syar'i. Istilah kepemimpinan lillah ini didasarkan kepada mencontoh Rasulullah saw. bahwa:

1. Pengalaman berbisnis yang diperoleh Muhammad sebelum ia menjadi Rasul merupakan hasil pergulatannya dengan realitas sosial. ${ }^{5}$ Muhammad menjadi pelaku bisnis sangat dipengaruhi oleh lingkungannya sejak ia kecil hingga dewasa, dan menikah dengan Khadijah. Dan setelah ia menjadi Rasul, sebagian pengalamannya dituangkan dalam sabdanya, yang disebut dengan hadis. ${ }^{6}$

2. Keberhasilan Muhammad dalam berbisnis dipengaruhi oleh kepribadian diri Muhammad yang dibangunnya atas dasar dialogis realitas sosial masyarakat Jahiliyyah dengandirinya. ${ }^{7}$

3. Kepemimpinan nabi Muhammad saw. sebagai seorang Rasulullah ucapannya itu tiada lain hanyalah wahyu yang diwahyukan (kepadanya), sehingga perihidup beliau menjadi contoh suri tauladan bagi manusia yang tiada taranya, termasuk dalam praktek kepemimpinan organisasi sosial keagamaan, dan lainnya.

4. Perihidup nabi sudah sepatutnya diterapkan dalam semua aspek kehidupan meliputi: hablun min al-Allāhi wa hablun min an-nāsi, seperti urusan ibadah, keluarga, pemerintahan (profesi), kemasyarakatan, dan lainnya, termasuk dalam usaha-usaha organisasi kemasyarakatan Islam dalam menjalankan visi dan misinya.

Oleh sebab itu kepemimpnan lillah (istilah penulis) di sini dengan mencontoh kepemimpinan rasulullah yang berdasarkan petunjuk inti ajaran Islam (Alquran dan hadis) diharapkan dapat diterapkan oleh Washliyun dalam menjalankan usaha-usahanya.Kepemimpinan tersebut berfungsi yaitu perencanaan, pengorganisasian, pengarahan, dan pengawasan terhadap usaha yang dijalankan. Dengan demikian jelaslah bahwa kepemimpinan sangat mempengaruhi terhadap pengembangan usaha. 
Dari sisi motivasi ekonomi syariah penting peranannya dalam pengembangan usaha berbasis syariah.Sebab motivasi sebagaimana dijelaskan oleh Stephen P. Chobbins dan Marry Coulter sebagaimana dikutip oleh Winardi bahwa motivasi adalah kesediaan untuk melaksanakan upaya dalam mencapai tujuan keorganisasian yang dikondisikan oleh kemampuan untuk memenuhi kebutuhan individual tertentu. ${ }^{8}$ Motivasi ekonomi syariah dapat dianalogikan — meski tidak seluruhnya tepat - misalnya kita akan membeli makanan di restauran/kedai nasi di daerah minoritas Muslim. Pertama kali yang dilihat adalah tampilan luar yang berlabel "halal" atau terdapat bacaan "Basmalah". Jika label itu dikaitkan dengan kehalalan, maka mendatangkan keyakinan halalnya, dan menepis keraguan haramnya. Demikian pula label usaha syariah. Artinya penggunaan label syariah tidak sekedar lebel, melainkan dalam praktek hendaklah sesuai syariat Islam, yang inti ajarannya adalah Alquran dan hadis. Jika demikian kecenderungan hati orang yang cinta agama atau bagi yang meyakini keunggulan produk-produk lembaga syariah, maka transaksi syariah menjadi pilihan dan motivasi baginya. Sebaliknya jika ternyata dalam prakteknya aktivitas tidak sesuai dengan label syariah, bisa membuat pelanggan kecewa, dan akibatnya usaha yang dikelola akan ditinggalkan. Di sinilah peran seorang pemimpin dalam kepemimpinannya agar mampu menggerakkan roda organisasi dengan memberikan motivasi kepada orang-orang (pengikut) nya, misalnya melalui sosialisasi motivasi ekonomi syariah tersebut. Sebab kepemimpinan merupakan proses mempengaruhi atau memberi contoh oleh pemimpin kepada pengikutnya dalam upaya mencapai tujuan organisasi. ${ }^{9}$

Dengan demikian dapat beragam yang menjadi motivasi orang dalam beraktivitas dan sangat tergantung pada apa yang dipahami tentang sesuatu itu, misalnya ia bekerja karena sesuai aspirasinya, tapi ada pula bekerja karena ingin pengakuan, atau pujian dari orang lain, dan ada yang bekerja karena sebagai ibadah sehingga ada keganderungan pada usaha yang syar'i. Ini menunjukkan bahwa motivasi ekonomi syariah turut mempengaruhi suatu usaha.

Dari sisi aset, bahwa aset merupakan semua hak yang dapat digunakan dalam operasi perusahaan.Yang dapat dimasukkan ke dalam kolom aset salah satunya adalah gedung atau bangunan.Jadi kalau suatu usaha memiliki gedung senilai satu miliar rupiah, maka aset yang dihitung adalah satu miliar rupiah itu. Selain gedung, yang bisa dihitung sebagai aset bisa termasuk: merk dagang, paten teknologi, uang kas, mobil, dan lain-lain. Aset dipahami sebagai harta total. Namun biasanya untuk keperluan analisis dirinci menjadi beberapa kategori, 
330 AT-TAWASSUTH: Jurnal Ekonomi Islam, Volume IV No. 2 Juli -

Desember 2019: 323 - 348

seperti: aset lancar, investasi jangka panjang, aset tetap, aset tidak tetap, aset tidak berwujud, aset pajak tangguhan, dan aset lainnya.

Di dalam istilah akuntansi, aset tetap merupakan salah satu pos di neraca di samping aset lancar, investasi jangka panjang, dana cadangan, dan aset lainnya. Aset tetap mempunyai peranan yang sangat penting karena mempunyai nilai yang cukup signifikan bila dibandingkan dengan komponen neraca lainnya. Aset Tetap menurut PSAK No. 16 adalah aset berwujud yang:

1. Dimiliki untuk digunakan dalam produksi atau penyediaan barang dan jasa untuk direntalkan kepada pihak lain, atau untuk tujuan administratif; dan

2. Diharapkan untuk digunakan selama lebih dari satu periode. ${ }^{10}$

Dalam kaitan penelitian ini, bahwa kondisi Al-Washliyah, di tengah arus kompetisi dunia usaha dan pendidikan yang semakin ketat, kondisi amal usaha AlWashliyah, baik itu disadari atau tidak, permasalahan utama yang sering muncul dan bahkan terus berulang dalam kaitan pengelolaan dan penataan, termasuk terhadap asset Al-Washliyah, ternyata belum tertib. Sekitar 35 persen sekolahsekolah/madrasah-madrasah (usaha AW lainnya - penulis) yang menggunakan lambang dan nama Al-Washliyah tetapi sesungguhnya tidak punya keterikatan/hubungan struktural terhadap organisasi. ${ }^{11}$

Dari sisi budaya organisasi, bahwa selain penciptaan hubungan antara kepemimpinan dan/karyawan, faktor lain yang paling sensitif dan dapat mempengaruhi pengembangan usaha ialah mengenai budaya organisasi.Menurut Hakim $^{12}$ konsep dasar yang menjadi landasan ekonomi Islam dapat dijadikan landasan budaya kerja sebagai budaya organisasi.

Dari sisi minat sebagaimana dikemukakan oleh Crow and Crow (1989) bahwa minat berhubungan dengan gaya gerak yang mendorong seseorang untuk menghadapi atau berurusan dengan orang, benda, kegiatan, pengalaman yang dirangsang oleh kegiatan itu sendiri. ${ }^{13}$ Misalnya, minat berusaha dapat dilihat dari kesediaan untuk bekerja keras dan tekun untuk mencapai kemajuan usahanya, kesediaan menanggung macam-macam resiko yang berkaitan dengan tindakan berusaha yang dilakukannya, bersedia menempuh jalur dan cara baru, kesediaan untuk hidup hemat, kesediaan dari belajar yang dialaminya.

Minat suatu perangkat mental yang terdiri dari kombinasi, perpaduan dan pencampuran dari perasaan, harapan, prasangka, cemas, takut dan kecenderungan- 
kecenderungan lain untuk bisa mengarahkan individu kepada suatu pilihan tertentu.Dengan demikian minat sangat besar pengaruhnya dalam mencapai kesiapan dan prestasi dalam suatu pekerjaan. Faktor-faktor yang mempengaruhi minat, antara lain: ${ }^{14}$

1) Dorongan dari dalam individu.Misal dorongan untuk makan. Dorongan untuk makan akan membangkitkan minat untuk bekerja atau mencari penghasilan, minat terhadap produksi makanan dan lain-lain.

2) Motif sosial. Dapat menjadi faktor yang membangkitkan minat untuk melakukan suatu aktivitas tertentu.

3) Faktor emosional. Minat mempunyai hubungan yang erat dengan emosi.

Dengan demikian minat merupakan dorongan kuat bagi seseorang untuk melakukan sesuatu dalam mewujudkan pencapaian tujuan dan cita-cita yang menjadi keinginannya. Selain itu minat dapat timbul karena adanya faktor eksternal dan juga adanya faktor internal, yang akan mempengaruhi terhadap usaha.

Dari sisi pemahaman, sebagaimana dikemukakn oleh Sudirman, pemahaman adalah suatu kemampuan seseorang dalam mengartikan, menafsirkan, menerjemahkan, atau menyatakan sesuatu dengan caranya sendiri tentang pengetahuan yang pernah diterimanya.Dan menurut Arikunto pemahaman (Comprehention) siswa diminta untuk membuktikan bahwa ia memahami hubungan yang sederhana diantara fakta-fakta. ${ }^{15}$ Dengan perkataan lain pemahaman mengandung makna kemampuan diri seseorang dalam kegiatan berpikir sehingga menjadi keyakinan pada dirinya, misalnya unuk melakukan atau tidak terhadap apa yang dipahaminya.

Di dalam Islam, nabi Muhammad saw. bersabda:
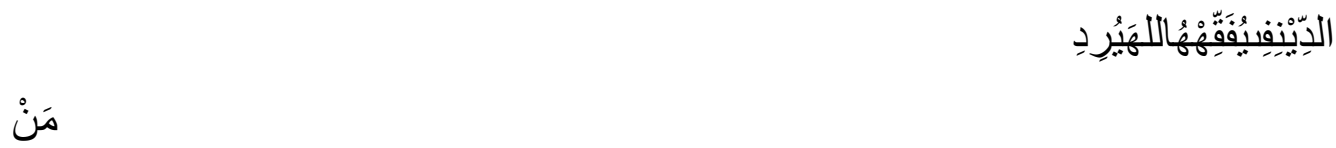

Artinya: "Barang siapa yang dikehendaki Allah swt.. menjadi orang yang baik di sisi-Nya, niscaya diberikan kepadanya pemahaman yang mendalam dalam pengetahuan agama”. (H. R. Bukhari). ${ }^{16}$

Hadis tersebut menjelaskan pentingnya pemahaman yang benar itu dalam kehidupan ini, namun hal itu diberikan Allah kepada oang yang Ia kehendaki, sehingga akivitasnya berorientasi kepada keridoan Allah swt. Sebagaimana Al- 
332 AT-TAWASSUTH: Jurnal Ekonomi Islam, Volume IV No. 2 Juli -

Desember 2019: 323 - 348

Qadhi 'Iyadh berkata, "Ini adalah dua kalimat yang agung, yaitu kalimat pertama mengandung pengertian bahwa 'amal ikhtiyar (amal perbuatan yang diusahakan) tidak akan menghasilkan pahala bila tidak didahului dengan niat yang tulus. Jadi, untuk amal perbuatan yang memberi peluang samarnya tujuan, maka harus diniatkan dan ditentukan dengan jelas. ${ }^{17}$ Dengan demikian semakin baik pemahaman Wshliyun terhadap pengembangan usaha berbasis syariah, maka akan semakin baik hasil dan capain usaha dalam menghadirkan kesejahteraan umat.

Dari uraian latar belakang di atas, bahwa ada sembilan faktor yang dapat mempengaruhi usaha berbasis syariah tersebut yaitu: organisasi, administrasi, manajemen, kepemimpinan, motivasi ekonomi syariah, aset, budaya organisasi, minat, dan pemahaman. Namun dalam penelitian ini penulis sengaja mempertimbangkan membahas pada faktor mana yang paling signifikan mempengaruhi usaha berbasis syariah. Berdasarkan pengamatan awal penulis dan berlandaskan teori dan pendapat ahli di atas, maka diduga ada fakor yang paling kuat pengaruhnya terhadap pengembangan amal usaha Washliyun tersebut. Dan akhirnya penulis memutuskan melakukan penelitian ini dengan judul di atas

Berdasarkan latar belakang masalah yang telah diungkapkan, maka yang menjadi maslah pokok dalam penelitian ini adalah bagaimana pengaruh kepemimpinan dan budaya organisasi terhadap pengembangan usaha berbasis syariah di kalangan Washliyun Provinsi Sumatera Utara.Penelitian ini secara umum bertujuan intuuk menjawab persoalan pokok di atas yaitu untuk mengetahui dan menganalisis pengaruh kepemimpinan dan budaya organisasi terhadap pengembangan usaha berbasis syariah di kalangan Washliyun Provinsi Sumatera Utara.

Penelitian ini diharapkan memberikan manfaat yaitu :

1. Bagi Pembaca. Penelitian ini diharapkan dapat menambah wawasan bagi para pembacanya tentang faktor-faktor yang berpengaruh terhadap pengembangan usaha berbasis syariah.

2. Bagi Kalangan Washliyin.

a. Sebagai bahan masukan bagi Washliyin Provinsi Sumatera Utara guna mengembangkan usaha berbasis syariah yang lebih baik ke depan.

b. Dapat memberi masukan atau pertimbangan-pertimbangan bagi AlWashliyah Provinsi Sumatera Utara dalam rangka menyusun strategi meningkatkan kwantitas dan kwalitas usaha berbasis syariah. 
c. Dapat dijadikan referensi tambahan untuk mengetahui apa yang telah dilaksanakan sehingga diharapkan bisa meningkatkan strategi pengembangan usaha berbasis syariah ke depan.

3. Bagi Akademisi. Penelitian ini diharapkan dapat memacu penelitian selanjutnya yang lebih baik mengenai faktor-faktor yang berpengaruh terhadap pengembangan usaha berbasis syariah di kalangan Washliyin Provinsi Sumatera Utara.

\section{Metode Penelitian}

Penelitian yang dilakukan ini tergolong sebagai penelitian lapangan (field research)..Oleh karena itu, obyek penelitiannya adalah berupa obyek di lapangan yang sekiranya mampu memberikan informasi tentang kajian penelitian.Dalam hal ini Washliyun Provinsi Sumatera Utara menjadi obyek penelitian dengan difokuskan pada pengaruh kepemimpinan dan budaya organisasi terhadap pengembangan usaha berbasis syariah.Jenis penelitian ini merupakan jenis penelitian kwalitatif.menggunakan pendekatan fenomenologis, melalui: a) Ketekunan pengamatan, b) Triangulasi Data, c) Kecukupan Referensi. Data hasil penelitian diolah melalui teknik: a) reduksi data, b) penyajian data, c) penarikan kesimpulan, yang bertujuan untuk mendapatkan data dalam menunjang hasil akhir penelitian.

\section{Hasil Penelitian dan Pembahasan}

Amal Usaha Washliyin Periode Tahun 1930-1985 (Ketika Kedudukan PB AW di Medan).

Amal usaha Washliyin yang utama adalah dakwah, pendidikan, dan sosial. Ketiga usaha ini oleh Washliyun menyebutnya dengan amal ittifaq. ${ }^{18} \mathrm{Hal}$ ini mempunyai dasar yaitu sesuai dengan situasi dan kondisi yang melatar belakangi lahirnya Al-Washliyah itu sendiri, sehingga dakwah, pendidikan, dan sosial menjadi tiga pilar utama pengembangan Al-Washluyah. ${ }^{19}$

\section{Amal Usaha WashliyinPeriode Tahun 1986-sekarang (Setelah Kedudukan PB AW Pindah ke Jakarta).}

Salah satu keputusan penting Muktamar Al-Washliyah XVI tahun 1986 di Jakarta adalah memindahkan kedudukan Pengurus Besar Al Jam'iyatul Washliyah 
334 AT-TAWASSUTH: Jurnal Ekonomi Islam, Volume IV No. 2 Juli -

Desember 2019: 323 - 348

dari Medan ke ibu kota Jakarta.Kemudian keputusan penting lainnya adalah menambah jenisamal usaha Al-Washliyah dari yang sudah ada yaitu mendirikan lembaga keuangan syariah. ${ }^{20}$

Selama tahun 1991 hingga 2019 ini, organisasi Al-Washliyah Sumatera Utara telah dipimpin oleh para kader terbaiknya dan sudah mengalami beberapa kali pergantian sejak kedudukan Pengurus Besar pindah ke Jakarta pada tahun 1986 yaitu sebagi berikut :

\begin{tabular}{|c|c|c|c|}
\hline \multirow[t]{2}{*}{ No } & \multirow[t]{2}{*}{ Pereode } & \multicolumn{2}{|l|}{ Pimpinan Wilayah } \\
\hline & & Ketua & Sekretaris \\
\hline 1 & 1989-1997 & Drs. H. Usman Serawi, LC & Ikhyar Hasibuan, BA \\
\hline 2 & $1998-2003$ & Drs. H. Abdul Halim Hrp. & H. Dariansyah Emde, SPd \\
\hline 3 & 2003-2005 & Drs. H. Abdul Halim Hrp. & Drs. H. Rijal Sirait \\
\hline 4 & $2006-2010$ & $\begin{array}{l}\text { Drs. H. Muhammad Nizar } \\
\text { Syarif }\end{array}$ & Drs. H. Rijal Sirait \\
\hline 5 & 2011-2015 & Drs. H. Hasbullah Hadi, MH & $\begin{array}{l}\text { Drs. H. Yulizar Parlagutan, } \\
\text { MSi }\end{array}$ \\
\hline 6 & $2015-2020$ & $\begin{array}{l}\text { Prof. Dr. H. Syaiful Akhyar } \\
\text { Lubis, MA }\end{array}$ & $\begin{array}{l}\text { H. Isma Fadli Ardya Pulungan, } \\
\text { SAg, SH, MH }\end{array}$ \\
\hline
\end{tabular}

Sumber :Sekretariat PWAW SU.

Di bawah kepemimpinan mereka, Al-Washliyah telah memberikan sejumlah kontribusi baik dalam bidang pendidikan, dakwah maupun amal sosial.Sejak berdiri, Al-Washliyah memang memiliki perhatian intens terhadap dunia pendidikan.Sebagai salah satu organisasi pembaharu, Al-Washliyah memainkan peranan tidak kecil bagi perubahan kondisi umat Islam di Provinsi Sumatera Utara khususnya, dan Indonesia pada umumnya.Sejarah membuktikan bahwa AlWashliyah memberikan perhatian cukup besar terhadap 3 (tiga) bidang yaitu dakwah,pendidikan, dan sosial. ${ }^{21}$

Pada periode kepemimpinan Drs. H. Usman Serawi LC dkk Al-Washliyah Sumatera Utara dalam menindaklanjuti kebijakan organisasi bidang usaha ekonomi adalahmembentuk majelis pembinaan dan pengembangan ekonomi umat Al-Washliyah Provinsi Sumatera Utara.Majelis itu pula yang kemudian mendirikan bank syariah Al-Washliyah tersebut, tahun 1994 dengan istilahnya modal pas-pasan. Modal pertama sebesar Rp. 93.410.000,- bisa mendirikan bank syariah yang diberi nama bank syariah PT. BPR Syariah Al-Washliyah.Periode awal berdiri bank syariah PT. BPR Syariah Al-Washliyah susunan majelisyaitu Ketua Ir. H. M. Arifin Kamdi MS dan Sekretaris Abdul Rahman Rais SE. Diharapkan usaha ekonomi smacam ini bisa memberikan kontribusi besar bagi 
Gerakan Ekonomi Syariah yang dicanangkan oleh Presiden Republik Indonesia Susilo Bambang Yudhoyono ketika itu. Hal itu disampaikan Gubernur Sumatera Utara H. Gatot Pujo Nugroho, ST, MSi dalam sambutannya pada acara peresmian kantor PT. Bank Pembiayaan Rakyat (BPR) Syariah Al-Washliyah di Jalan Gunung Krakatau No. 28 Medan, Senin tanggal 6 Januari 2014. ${ }^{22}$ Komisaris Utama PT BPR Syariah Al-Washliyah Drs. H. Hasbullah Hadi, SH, MH menyebutkan, sejak didirikan tahun 1994 dengan modal hanya sekitar Rp. 93 juta tersebut. Hingga pada tahun 2014 bank syariah PT. BPR Syariah Al-Washliyah telah memiliki aset mencapai Rp. 13 miliar.

Dalam bidang usaha pendidikan Al-Washliyah Sumatera Utara menyelenggarakan pendidikan pendidikan agama dan umum mulai dari tingkat Taman Kanak-Kanak (TK) sampai Perguruan Tinggi (PT).Sedangkan bidang usaha (sosial) Al-Washliyah Sumatera Utara mendirikan 9 panti asuhan dan sebuah rumah sakit Al-Washliyah.Lihat tabel I.1 tentang amal usaha AlWashliyah Sumatera Utara di bawah ini.

Tabel 1 Amal Usaha Al-Washliyah Sumatera Utara Tahun 2003. ${ }^{23}$

\begin{tabular}{|c|c|c|}
\hline No & Amal Usaha & Jumlah \\
\hline \multirow[t]{2}{*}{1} & Bidang Kepengurusan/Organisasi: & \\
\hline & Pimpinan Daerah & $\begin{array}{l}26 \text { Pimpinan Daerah dari } 33 \\
\text { kota/kabupaten se-SU }\end{array}$ \\
\hline \multirow[t]{7}{*}{2} & Bidang Pendidikan Dasar dan Menengah: & \\
\hline & Sekolah Umum & 148 buah \\
\hline & Sekolah Agama & 461 buah \\
\hline & Pendidikan Lainnya & 76 buah \\
\hline & Bidang Pendidikan Tinggi: & \\
\hline & Universitas & 2 buah \\
\hline & Sekolah Tinggi & 1 buah \\
\hline \multirow[t]{2}{*}{3} & Bidang Ekonomi: & \\
\hline & $\begin{array}{l}\text { Bank Syariah Bank Perkreditan Rakyat } \\
\text { (BPR) }\end{array}$ & 1 buah \\
\hline \multirow[t]{3}{*}{4} & Bidang Sosial: & \\
\hline & Rumah Sakit/Klinik & 1 buah \\
\hline & Panti Asuhan & 9 buah \\
\hline
\end{tabular}

Dari data di atas menunjukkan, bahwa Al-Washliyah memiliki potensi dan jaringan organisasi yang memungkinkan untuk bisa mengembangkan usahausahanya. Sebab dari beberapa penelitian, misalnya menurut penelitian DR. Hj. Chadijah Hasan dalam desertasinya yang kemudian dijadikan sebuah buku berjudul “Al-Washliyah api dalam sekam”, organisasi Al Jam'iyatul Washliyah 
336 AT-TAWASSUTH: Jurnal Ekonomi Islam, Volume IV No. 2 Juli -

Desember 2019: 323 - 348

berada pada urutan ketiga organisasi Islam terbesar di Indonesia sesudah Nahdlatul Ulama (NU) dan Muhammadiyah. ${ }^{24}$ Dengan demikian dapat dikatakan kepengurusan Al-Washliyah di Sumatera Utara memiliki jaringan yang terluas dibandingkan ormas Islam lainnya, sebagaimana ditunjukkan dalam data amal usaha Al-Washliyah Sumatera Utara pada tabel I.1 di atas. Ini semua merupakan potensi bagi organisasi Al-Washliyah, baik usaha yang dikelola langsung oleh pengurus, maupun usaha yang dikelola oleh pihak lain dengan memakai nama $\mathrm{Al}$ Washliyah. Usaha organisasi Al-Washliyah ini terus dikembangkan.

Namun seiring waktu berjalan terjadi dinamika organisasi ini, sehingga berdasarkan data terakhir amal usaha Al-Washliyah Sumatera Utara terjadi pasang surut, dapat dilihat pada tabel 2 di bawah ini.

Tabel 2 Amal Usaha Al-Washliyah Sumatera Utara Tahun 2018

\begin{tabular}{|c|c|c|}
\hline No. & Amal Usaha & Jumlah \\
\hline \multirow[t]{2}{*}{1} & Bidang Kepengurusan/Organisasi: & \\
\hline & $\begin{array}{l}\text { Pimpinan Daerah Al-Washliyah, dan } \\
\text { Organisasi Bahagian (Muslimat, GPA, APA, } \\
\text { IPA, HIMMAH, ISARAH, dan IGA) }\end{array}$ & $\begin{array}{ll}27 & \text { Pimpinan Daerah } \\
\text { dan } & \text { Organisasi Bagian } \\
\text { dari } 33 \text { Kota/Kabupaten } \\
\text { se-SU }\end{array}$ \\
\hline \multirow[t]{8}{*}{2} & Bidang Pendidikan Dasar dan Menengah: & \\
\hline & Taman Kanak-Kanak (TK) & 9 buah \\
\hline & Madrasah Ibtidaiyah (MID) & 41 buah \\
\hline & Sekolah Dasar (SD) & 96 buah \\
\hline & Sekolah Lanjutan Tingkat Pertama (SLTP) & 15 buah \\
\hline & Bidang Perguruan Tinggi: & \\
\hline & Universitas & 2 buah \\
\hline & Sekolah Tinggi Ilmu Ekonomi & 1 buah \\
\hline \multirow[t]{2}{*}{3} & Bidang Ekonomi: & \\
\hline & Bank Syariah PT. BPR Syariah & 1 buah \\
\hline \multirow[t]{3}{*}{4} & Bidang Sosial: & \\
\hline & Panti Asuhan & 9 buah \\
\hline & Rumah Sakit/Klinik 25 & 0 buah \\
\hline
\end{tabular}

Sumber: $A W S U$.

Dari data di atas menunjukkan, bahwa segi kepengurusan Al-Washliyah Sumatera Utara bertambah dari totoal 26 Pimpinan daerah naik menjadi 27 Pimpinan Daerah.Namun dari usaha sosial rumah sakit/klinik Al-Washliyah menurun dari ada satu unit menjadi nihil atau yang ada sebelumnya satu unit ditutup pada tahun 2004, tidak beroperasi lagi. ${ }^{26}$ Meskipun kemudian lokasi gedung eka-Rumah Sakit/Klinik Al-Washliyah tersebut akan dialih-fungsikan untuk dibangun dijadikan gedung perkuliahan Universitas Muslim Nusantara 
(UMN) Al-Washliyah Medan. Gedung kuliah itu diberi nama gedung Syech Muhammad Yunus. ${ }^{27}$

Potensi Al-Washliyahsebagai organisasi kemasyarakatan Islam terbesar ketiga di Indonesia, dan terbesar di Sumatera Utara, memiliki potensi dan jaringan sehingga menjadi memiliki peluang mengembangkan usaha seluas sruktur kepemimpinan organisasi. Namun Al-Washliyah memiliki permasalahan utama dalam mengembangkan usaha. Dan logis jika pimpinan Al-Washliyah dan banyak pihak menginginkan kemajuan dan kejayaan Al-Washliyah di tengah usianya yang semakin matang. Kiprah dan gerakan dakwah, pendidikan serta amal sosial yang menjadi khittah perjuangan organisasi harus dapat dipertahankan dan ditingkatkan.Harus pula diakui secara jujur, bahwa didapati berbagai permasalahan yang masih terus mengitari Al-Washliyah, baik itu internal maupun eksternal.

Beberapa persoalan internal itu antara lain; kaderisasi, pengelolaan, regulasi, pendidikan, aset dan harta organisasi, dakwah dan penyantunan fakir miskin, serta hal lain yang perlu segera dicari solusi penyelesaiannya. Tentu saja, Washliyin dan Washliyat berpendirian, bahwa terkait harta dan aset organisasi berupa lembaga pendidikan (sekolah/madrasah) yang telah diwarisi oleh para pendahulu untuk dikelola bagi kepentingan umat. Aktifitas terpenting yang menjadi amal ittifaq Al-Washliyah adalah dakwah, pendidikan, dan sosial; yang kemudian sejak tahun 1994 mulai mengemangakan usaha ekonomi bank syariah yang disebut PT. BPR Syariah Al-Washliyah.

Selanjutnya aktifitas usaha pendidikan yang terus berjalan di lingkungan AlWashliyah menandakan bahwa eksistensi sebagai sebuah organisasi kemasyarakatan masih tetap bertahan. Al-Washliyah sebagai organisasi kemasyarakatan Islam terbesar ketiga di Indonesia, lahir dan terbesar di Sumatera Utara akan terus berkiprah mengembangkan amal usahanya zaman ber-zaman. Sudah selama 89 tahun Al-Washliyah ikut serta berpartisipasi secara aktif mencerdaskan kehidupan bangsa baik kecerdasan intelektual maupun kecerdasan spiritual.Sejak tahun 1994 melaksanakan pembinaan dan pengembangan ekonomi, yaitu mendirikan bank syariah PT. BPR Syariah Al-Washliyah.Karenanya dibutuhkan kepastian, ketegasan dan profesinalisme dalam hal penataan dan pengelolaan amal usaha Al-Washliyah tersebut agar bisa kompetitif dengan lembaga atau organisasi lainnya, baik negeri maupun swasta. 
338 AT-TAWASSUTH: Jurnal Ekonomi Islam, Volume IV No. 2 Juli -

Desember 2019: 323 - 348

Permasalahannya kini Al-Washliyah berada di tengah arus kompetisi dunia usaha yang semakin ketat, kondisi amal usaha Al-Washliyah, baik itu disadari atau tidak, permasalahan utama yang sering muncul dan bahkan terus berulang dalam kaitan pengelolaan dan penataan. Dengan perkataan lain manajemen kepemimpian dan pengelolaan yang belum tertib. Contohnya masih banyak dijumpai usaha, sekolah-sekolah/madrasah-madrasah yang menggunakan lambang dan nama Al-Washliyah tetapi sesungguhnya tidak punya keterikatan/hubungan struktural terhadap organisasi.

Hal ini menjadi keprihatinan banyak tokoh dan pengurus Al-Washliyah, karena sesungguhnya apa yang hari ini menjadi aset organisasi adalah warisan para pendahulu organisasi. Sebagian besar harta organisasi tersebut adalah wakaf yang selanjutnya dititipkan sebagai amanah kepada Al-Washliyah untuk mengelolanya. ${ }^{28}$ Dengan demikian timbul pertanyaan faktor-faktor apakah yang mempengaruhi pengembangan usaha Al-Washliyah tersebut.Beranjak dari permasalahan utama inilah hingga menjadi perhatian penulis melakukan penelitian ini, untuk mengetahui faktor-faktor yang paling mempengaruhi pengembanngan usaha berbasis syariah di kalangan Al-Washliyah Sumatera Utara.

Dapat dikatakan bahwa maju mundurnya suatu organisasi turut ditentukan atau dipengaruhi oleh kepoemimninan dan budyaya organsiasi..

a. Pengaruh kepemimpinan terhadap usaha.

Kepemimpinan dapat mempengaruhi pengembangan suatu usaha.Menurut Ordway Tead (dalam Sutarto, 1986: 12) bahwa kepemimpinan adalah aktivitas mempengaruhi orang-orang agar mau bekerja sama untuk mencapai beberapa tujuan yang mereka inginkan. Kepemimpinan diibaratkan sebagai sebuah alat atau sarana untuk memengaruhi seorang atau sekelompok orang agar bersedia melakukan sesuatu secara sukarela seperti apa yang telah direncanakan diawal pemikiran seorang pemimpin itu sendiri. Seorang pemimpin akan dituntut secara terus menerus untuk memunculkan ide-ide kreatifnya agar usaha yang dijalankannya bisa meningkatkan performancenya dalam segala bidang dan bisa bertahan atau bisa beradaptasi dalam perubahan lingkungan. Pada hakikatnya kepemimpinan adalah proses memengaruhi atau memberi contoh dari pemimpin kepada pengikutnya dalam upaya mencapai tujuan organisasi. ${ }^{29}$ Seperti yang dijelaskan dalam Alquran Surat Al-Anbiya: 21; 73:

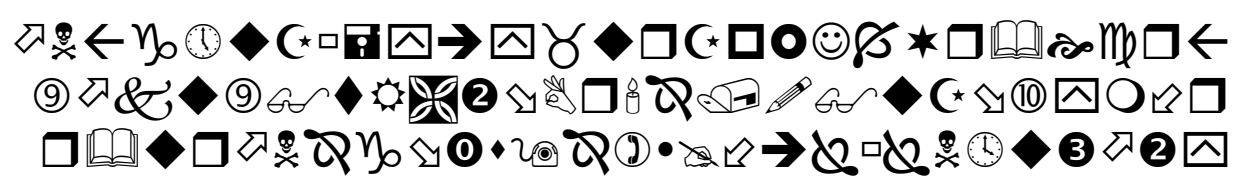




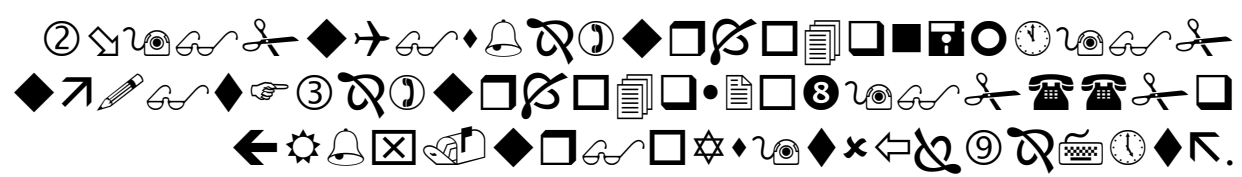

Artinya: Kami telah menjadikan mereka itu sebagai pemimpin-pemimpin yang memberi petunjuk dengan perintah Kami dan telah Kami wahyukan kepada, mereka mengerjakan kebajikan, mendirikan sembahyang, menunaikan zakat, dan hanya kepada kamilah mereka selalu menyembah. ${ }^{30}$

Kepemimpinan sangat erat hubungannya dengan kekuasaan pemimpin dalam memperoleh alat untuk mempengaruhi perilaku para pengikutnya. ${ }^{31}$ Dalam melaksanakan aktivitasnya pemimpin dipengaruhi oleh berbagai macam faktor. Faktorfaktor tersebut sebagaimana dikemukakan oleh H. Jodeph Reitz (1981) yang dikutif Nanang Fattah, sebagai berikut :

1) Kepribadian (personality), pengalaman masa lalu dan harapan pemimpin, hal ini mencakup nilai-nilai, latar belakang dan pengalamannya akan mempengaruhi pilihan akan gaya kepemimpinan.

2) Harapan dan perilaku atasan.

3) Karakteristik, harapan dan perilaku bawahan mempengaruhi terhadap apa gaya kepemimpinan.

4) Kebutuhan tugas, setiap tugas bawahan juga akan mempengaruhi gaya pemimpin.

5) Iklim dan kebijakan organisasi mempengaruhi harapan dan perilaku bawahan.

6) Harapan dan perilaku rekan. ${ }^{32}$

Sebagian besar orang menganggap pemimpin sebagai sumber pengaruh, karena pada dasarnya seorang pemimpin mempengaruhi para pengikut atau sebagai pihak yang dipengaruhi (Rivai, 2005).Yang dimaksud kepemimpinan dalam konteks ini adalah kepemimpinan yang Islami yaitu kegiatan menuntun, membimbing, memandu dan menunjukkan jalan yang diridhai Allah swt.Jadi orientasi utama dalam kepemimpinan Islam adalah keridhaan Allah (Nawawi, 1993).

Dapat disimpulkan bahwa kepemimpinan Islam merupakan cara memimpin dari seorang pemimpin yang dapat menjaga amanah dan tanggungjawabnya kepada anggota dan Allah swt. yang berdasarkan pada 
Alquran dan hadis, sehingga hal ini akan beerdampak positif terhadap pengembangan usaha. Dalam hal ini organisasi Al-Washliyah menerapkan manajemen, administrasi, dan kepemimpinan dalam rangka meningkatkan pelayanan dan pengembangan usaha-usaha sesuai tuntutan AD/ARTnya.Sebab di dalam sebuah organisasi antara manajemen, kepemimpinan dan administrasi merupakan suatu kesatuan yang tidak dapat dipisahkan.Yang paling utama memegang peranan penting dalam unsur manjemen adalah faktor masnusia.Administrator menggunakan para manajer/eksekutif untuk mencapai tujuannya. Tindakan atau kemampuan untuk memperoleh hasil yang diinginkan dengan menggunakan orang-orang yang mempunyai keahlian khusus biasa disebut "kepemimipinan" (“leadership"). Oleh sebab itu, manajemen harus dilaksanakan dalam seluruh tingkat organisasi dari tingkat paling atas sampai tingkat paling bawah.Dan inti perbuatan dalam setiap usaha yang dikembangkan adalah kepemimpinan yang baik dan tepat.

Keterkaitan antara Administrasi, Manjemen dan Kepemimpinan dapat dianalogikan — meski tidak seluruhnya tepat—misalnya kita akan membeli sebuah durian.

Gambar 2

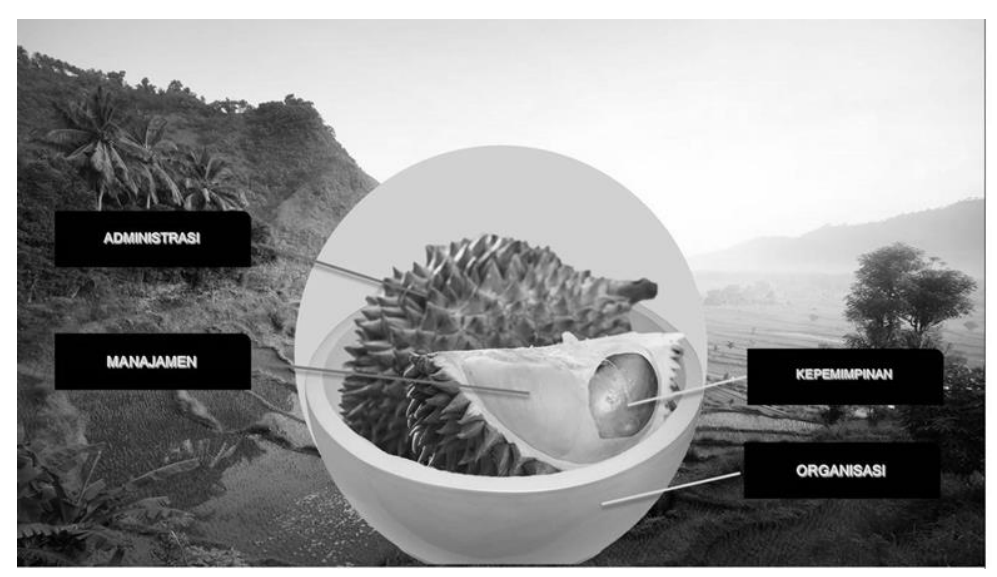

Pertama kali yang terlihat adalah kulit luar yang berwama kekuningkuningan. Jika kulitnya dikupas maka didapati daging durian yang berwarna kuning kalau dagingnya sudah dimakan maka akan terlihat intinya yang disebut biji durian. Demikian pula manajemen, maka yang pertama disoroti adalah kulit luamya yaitu “administnisi”.Kedua dagingnya yaitu “manajemen”, selanjutnya adalah bijinya yaitu “kepemimpinan”.Ini sebagai isyarat bahwa antara 
administrasi, manajemen dan kepemimpian merupakan suatu kesatuan yang tidak terpisahkan.Dengan demikian dapat dipahami bahwa kepepmimpinan merupakan faktor paling berpengaruh dalam suatu usaha.

\section{b. Pengaruh budaya organisasi terhadap usaha.}

Budaya Organisasi dapat mempengaruhi pengembangan suatu usaha.Selain penciptaan hubungan antara kepemimpinan dan karyawan, faktor lain yang paling sensitif dan dapat mempengaruhi pengembangan usaha ialah mengenai budaya organisasi.Peran budaya organisasi bagi pengembangan usaha, sebagaimana dikemukakan oleh Hakim (2011) konsep dasar yang menjadi landasan ekonomi Islam dapat dijadikan landasan budaya kerja sebagai budaya organisasi. Budaya tersebut antara lain didasarkan pada tiga konsep fundamental, yaitu; keimanan kepada Allah (tauhid), kepemimpinan (khilafah) dan keadilan (a'dalah). Dalam Alquran telah diterangkan bahwa di dunia ini terdiri dari berbagai macam budaya dan Allah memberikan isyarat agar kita melakukan interaksi dan memilah mana budaya yang terbaik dalam berorganisasi. Seperti firman-Nya dalam Q.S. Al-Hujurat: 49; 13:

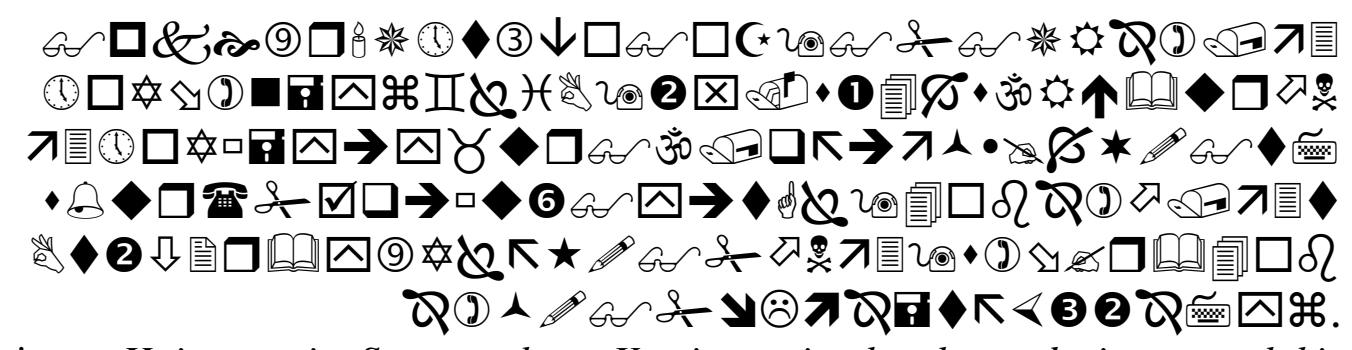

Artinya: Hai manusia, Sesungguhnya Kami menciptakan kamu dari seorang lakilaki dan seorang perempuan dan menjadikan kamu berbangsa - bangsa dan bersuku-suku supaya kamu saling kenal-mengenal. Sesungguhnya orang yang paling mulia diantara kamu di sisi Allah ialah orang yang paling taqwa di antara kamu.Sesungguhnya Allah Maha mengetahui lagi Maha Mengenal. ${ }^{33}$

Budaya organisasi dapat menjadi instrumen keunggulan kompetitif yang utama, ketika budaya organisasi mendukung strategi organisasi dan dapat menjawab atau mengatasi tantangan lingkungan dengan cepat dan tepat. ${ }^{34} \mathrm{Jadi}$ melalui budaya organisasi seorang pemimpin dapat mengawasi perilaku pegawai, kerjasama yang tercipta, cara mereka berfikir dan bagaimana cara mereka berinteraksi dengan lingkungannya. Jika budaya organisasi baik maka akan dapat 
342 AT-TAWASSUTH: Jurnal Ekonomi Islam, Volume IV No. 2 Juli -

Desember 2019: 323 - 348

meningkatkan prestasi maupun kinerja pegawai dan menyumbangkan keberhasilan untuk pengembangan usaha. Tentu yang dimaksud adalah budaya organisasi yang positif terhadap pengembangan usaha berdasarkan petunjuk syariat.Ini menunjukkan bahwa budaya organsiasi sangat mempengaruhi dalam suatu usaha.

Usaha Berbasis Syariah berarti usaha yang dijalankan berdasarkan petunjuk syariat Islam.Firman Allah swt.di dalam Alquran surat al-Baqarah: 2; 112:

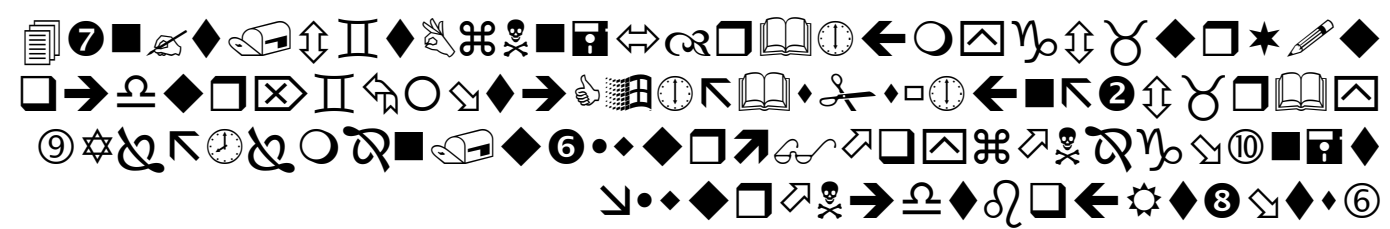

Artinya: (Tidak demikian) bahkan Barangsiapa yang menyerahkan diri kepada Allah, sedang ia berbuat kebajikan, Maka baginya pahala pada sisi Tuhannya dan tidak ada kekhawatiran terhadap mereka dan tidak (pula) mereka bersedih hati. ${ }^{35}$

Setiap orang yang berusaha tentu memiliki tujuan tertentu pula. Paling tidak ada 6 tujuan bisnis syariah yang sangat penting yaitu:

1) Memperoleh keuntungan material dan nonmaterial.

2) Mendorong terjadinya pertumbuhan ekonomi.

3) Menjaga keberlangsungan bisnis.

4) Memperoleh berkah dari Allah.

5) Mendapat rida Allah.

6) Mendapatkan ketenangan lahir dan batin. ${ }^{36}$ Usaha syariah berarti "serangkaian aktivitas jual beli dalam berbagai bentuknya yang tidak dibatasi jumlah kepemilikan hartanya baik barang atau jasa, tetapi cara memperoleh dan menggunakannya dibatasi dengan ketentuan syariah. Baik dalam mendapatkan harta dan menggunakannya tidak boleh dengan caracara yang diharamkan Allah, melainka yang dihalalkan-Nya. Sesuai firman Allah dalam surat al-Baqarah : $2 ; 42$ :

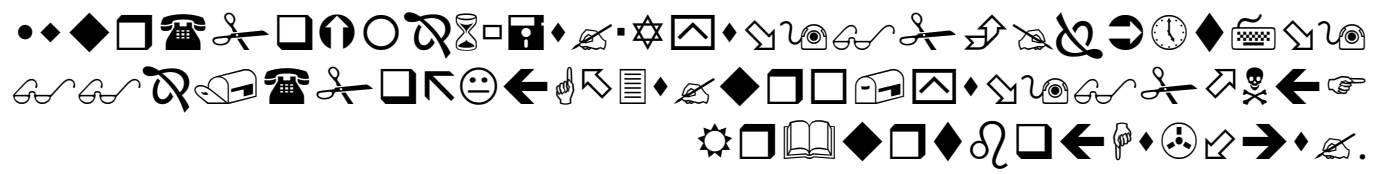

Artinya: Dan janganlah kamu campur adukkan yang hak dengan yang bathil dan janganlah kamu sembunyikan yang hak itu, sedang kamu mengetahui. ${ }^{37}$

Dengan demikian setiap usaha ketentuan syari'ah tidak boleh bersifat liberal atau bebas, tetapi harus mengikuti norma halal, haram bahkan yang syubhat lebih baik dijauhi dari pada dilakukan. Orang Islam yang tidak memperhatikan ketentuan-ketentuan tersebut, maka keuntungan yang diperolehnya tidak mendapat rido Allah.

Dalam hal ini Al-Washliyah mengembangkan usaha berbasis syariah merupakan salah satu jalan bagi organisasi melaksanakan ajaran Islam bersama para anggotanya maupun masyarakat luas.Usaha berbasis syariah berarti kegiatan ekonomi berlandaskan syariat Islam.Hanya melalui penyerahan diri kepada Allah swt.dan ketundukan atas hukum-Nya, termasuk pengurus dan 
anggota organisasi akan dapat mencapai kedamaian sejati dan menikmati kesucian diri. Firman Allah swt.di dalam Alquran surat ađ-Ďāriyāt: 51; 56:

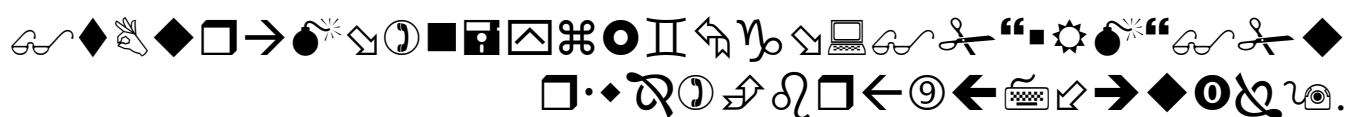
Artinya: Dan Aku tidak menciptakan jin dan manusia melainkan supaya mereka mengabdi kepada-Ku. ${ }^{38}$

Alquran menjelaskan agar manusia menjalani hidup menurut syariat Islam sehingga mendapatkan penghidupan yang baik, memenuhi segala kebutuhan dan kemakmuran hidup.Itu sebabnya Islam memerintahkan umatnya untuk senantiasa bekerja keras, dikarenakan pada berbagai belahan bumi yang luas ini terdapat karunia Allah Yang Maha Kaya, namun manusia perlu kerja keras mendapatkannya. Hal ini dijelaskan dalam Alquran surat al-Qaśaś: 28; 73:

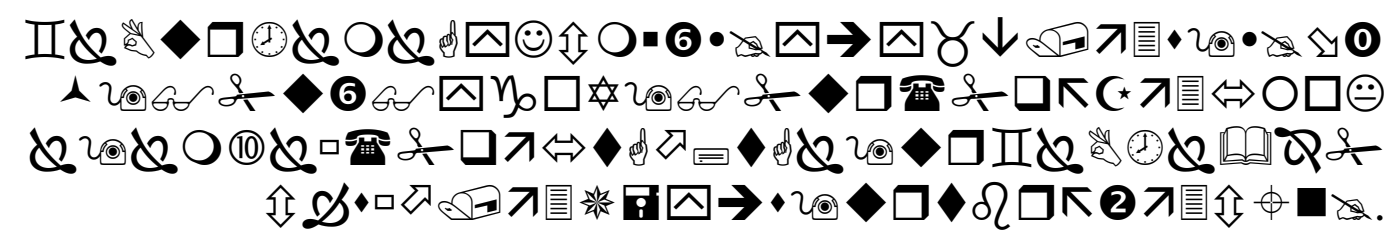

Artinya: "Dan karena rahmat-Nya, Dia jadikan untukmu malam dan siang, supaya kamu beristirahat pada malam itu dan supaya kamu mencari sebahagian dari karunia-Nya (pada siang hari) dan agar kamu bersyukur kepada-Nya." 39

Idealnya semua peringkat manajemen dapat menjalankan fungsi dan tugas masing-masing dalam rangka mengamalkan ajaran agama, dalam wadah oiganisasi sehingga membangkitkan diri memiliki minat dan motivasi kerja yang baik dan tinggi. Seorang pimpinan organisasi yang berpijak pada syariah Islam akan menempatkan hukum lima sebagai panglima. Hal ini dapat dimisalkan, bahwa dengan maraknya sistem bisnis global yang berbasil jual beli saham haram, maka manajemen tidak akan pernah mengikuti arus tersebut. Demikian halnya ketika instrumen kantor menuntut menggunakan IT berupa jaringan internet artau media sosial (medsos), maka akan diadaptasi secara positif (dibutuhkan ada manfaat) nya demi untuk suksesnya organisasi yang mengembangkan usaha berbasis syariah.

Merelealisasikan maqashid syariah di kalangan Al-Washliyah sejalan dengan lvisi dan misi oganisasi yaitu sebagai berikut:

Visi Al-Washliyah adalah melaksanakan hablum minallah wa hablum minannas dan turut menciptakan Negara yang baldatun thayyibatun wa rabbun ghofur, serta terwujudnya kehidupan masyarakat Indonesia yang Islami. Dan Misi Alwashliyah adalahMembangun umat masyarakat dan bangsa Indonesia untuk bertakwa kepada Allah swt. dan berpengatahuan luas serta berakhlak mulia.

Al-Washliyah mengelola amal usaha di bidang ekonomi, pemdidikan, dan sosial.Dan berusaha menemukan pemahaman atas hal-hal yang dapat dijadikan (solusi) motivasi yang bermanfaat bagi pihak-pihak terkait.Sebab motivasi berfungsi sebagai pengarah jalan yang menentukan pola-pola kehidupan dan tingkah laku perbuatan.Ia menjadi kunci utama dalam menafsirkan dan melahirkan perbuatan manusia. Peranan yang demikian menentukan ini, dalam 
344 AT-TAWASSUTH: Jurnal Ekonomi Islam, Volume IV No. 2 Juli -

Desember 2019: 323 - 348

konsep Islam motivasi lebih dikenal dengan istilah "niat", sebagaimana hadis Rasulullah saw., yang diriwayatkan Bukhari dan Muslim yang berbunyi:

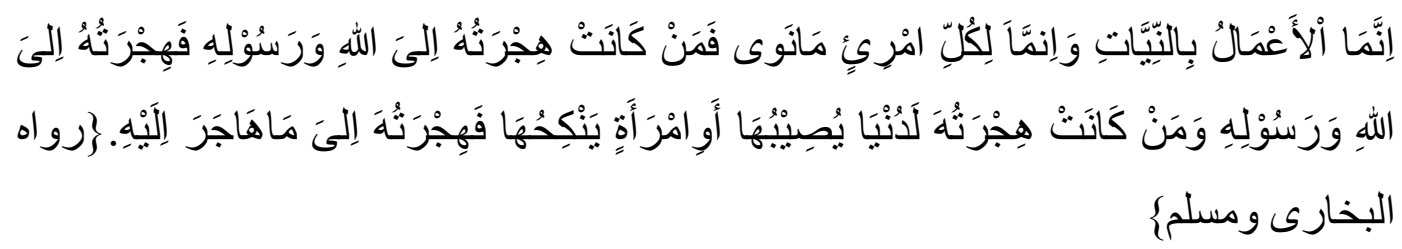

Artinya: "Bahwa segala amal perbuatan itu dengan niat, dan bagi setiap manusia itu apa yang diniatkanya. Maka siapa yang hijrah (keberangkatanya) pada Allah dan Rasul-Nya, maka hijrahnya pada Allah da rasul-Nya. Dan siapa yang hijrahnya pada dunia yang akan diperolehnya atau wanita yang akan dikawininya, maka hijrahnya kepada apa, yang ia berhijrah kepadanya. ${ }^{40}$

Al-Qadhi 'Iyadh berkata, "Ini adalah dua kalimat yang agung, yaitu kalimat pertama mengandung pengertian bahwa camal ikhtiyar (amal perbuatan yang diusahakan) tidak akan menghasilkan pahala bila tidak didahului dengan niat yang tulus. Jadi, untuk amal perbuatan yang memberi peluang samarnya tujuan, maka harus diniatkan dan ditentukan dengan jelas. ${ }^{41}$

Budaya merupakan seperangkat nilai yang berguna bagi penetapan konsep hidup manusia. Jika manusia ingin sukses dalam hidupnya maka sesorang harus mengetahui budaya orang lain di sekitarnya. Apabila kita hidup dalam lingkungan organisasi maka budaya organisasi yang mengelilingi harus kita pahami. Setelah memahami budaya hidup orang lain, maka langkah berikutnya adalah bagaimana merancang konsep strategik untuk mencapai sasarn yang diinginkan. Proses perencanaan dan pelaksanaan yang berorientasi ke masa depan menjadi bagian dari strategik manajemen. Dalam proses pelaksanaan rencana strategik diperlukan pemimpin yang tangguh yang mampu mempengaruhi semua pengikut dalam suatu

Membangun budaya organisasi/budaya perusahaan tidaklah mudah untuk menciptakanya. Terciptanya budaya organisasi melalui proses yang panjang dan secara bertahap berkelanjutan. Adapun budaya organisasi bisa tumbuh karena nilai budaya dibawa pendiri, Nilai di perkenalkan, Nilai divalidasi, Nilai menjadi budaya, Nilai ditanamkan, Nilai diperkuat, Budaya diperkuat, Budaya dipersoalkan, Budaya dirubah, Budaya baru divalidasi ulang.Kekuatan budaya organisasi ditentukan oleh kedalaman penghayatan nilai-nilai inti, kejelasan pengaturnya, dan keluasan penyebarannya dikalangan segenap anggota.Budaya organisasi merupakan hal yang peting karena salah satu modal untuk memanajemen strategik organisasi.Strategi adalah suatu kesatuan rencana komperhensif dan terpadu yang menghubungkan kekuatan strategi perusahaan dengan lingkungan yang dihadapi guna menjamiin tercapainya tujuan dan sasaran. 


\section{Kesimpulan.}

1. Kepemimpinan merupakan aspek penting yang mempengaruhi pengembangan usaha berbasis syariah di kalangan Washliyin Provinsi Sumatera Utara, baik untuk merencanakan memulai usaha, pengembangan usaha, maupun proses penanganan kegiatan internal dan eksternalyang melibatkan anggota/karyawan dan pihak-pihak terkait lainnya. Kepemimpinan di sini masih belum maksimal untuk bisa mengembangkan usaha-usaha Al-Washliyah tersebut. Meskipun terjadi inovasi baru dalam usaha Al-Washliyah yaitu berdirinya bank syariah PT. BPR Syariah AlWashliyah di Medan. Namun terdapat usaha yang sudah ada namun karena tidak terkelola dengan baik, akhirnya ditutup, tidak beroperasi lagi yaitu eksrumah sakit/klinik Al-Washliyah Jl. Gedung Arca Stadion Teladan Medan.

2. Budaya organisasi di kalangan Washliyin Provinsi Sumatera Utara ada yang berubah dari sebelumnya didominasi tradisi keulamaan, misalnya sekarang ini sudah masuk dari unsur politisi di dalam kepemimpinan. Keadaan ini tentu berpengaruh terhadap budaya organisasi. Dan hal ini bisa berpengaruh positif maupun negatif terhadap pengembangan usaha berbasis syariah bidang ekonomi, pendidikan, dan sosial di kalangan Washliyun Provinsi Sumatera Utara. Satu sisi keberadaan pengurus Al-Washliyah tampak kekinian karena bisa hadir dengan keadaan yang lebih mewah dari masa-masa sebelumnya, misalnya hadir dengan mobil-mobil peribadi dan lainnya. Di sisi lain budaya organisasi yang ada saat ini belum berpengartuh signifikan terhadap pengembangan usaha berbasis syariah di kalangan Washliyin Provinsi Sumatera Utara.

\section{Daftar Pustaka}

Lussier, Robert N. Achua, Christopher F. LEADERSHIP Theory, Application, \& Skill Development 4th edition. USA: South-Western Cengage Learning, 2010.

Hamzah Zakub, Menuju Keberhasilan, Manajemen dan Kepemimpinan, (Bandung: Diponegoro).Veithzal

Rivai, Kepemimpinan dan Prilaku Organisasi, Jakarta: Rajawali Pers, 2012.

Pandji Anoraga,Manajemen Bisnis, (Jakarta: Rineke Cipta, 2004.

Ahmad Ibrahim Abu Sinn, Manajemen Syariah Sebuah Kajian Historis dan Kontempore, (akarta: RajaGrafindo Persada, 2006.

Nanang Fattah, Landasan Manajemen Pendidikan, Bandung : Rosdakarya, 1996. Maman Ukas, Manajemen Konsep, Prinsip, dan Aplikasi, Bandung : Ossa Promo, 1999. 
346 AT-TAWASSUTH: Jurnal Ekonomi Islam, Volume IV No. 2 Juli -

Desember 2019: 323 - 348

Ahmad Sunarto, Terjemah Riyadhus Şālihin Jilid I, Jakarta: Pustaka Amani, 1999. M.Quraish Shihab,Tafsir al-Mishbah Pesan, Kesan, dan keserasian alQur'an,Volume2, Cet 1, Ciputat: Lentera Hati, 2000.Sayyid Quthb,Tafsir fi Zhilalil Qur'an, (terj), As'ad Yasin, Jakarta:GemaInsani Press, 2002.

Jarwanto, Pengantar Manajemen (3 IN 1), Mediatera, Yogyakarta, 2015. 1997.

Siagian, Sondang Palan. Filsafat Administrasi, Jakarta: Gunung Agung,

\section{Catatan}

${ }^{2}$ Edy Purwo Saputro, Dosen Pascasarjana UniversitasMuhammadiyah Solo.Artikel: $N U$, Muhammadiyah, dan Penguatan Ekonomi; diupload padaMinggu, 26 November 2017.14:22| Minggu, 26 November 2017 | 14:22. Lihat juga https://id.beritasatu.com/home/numuhammadiyah-dan-penguatan-ekonomi/168407.

${ }^{3}$ Kapitalisme atau kapital adalah sistem ekonomi dimana perdagangan, industri dan alat-alat produksi dikendalikan oleh pemilik swasta dengan tujuan memperoleh keuntungan dalam ekonomi pasar. Pemilik modal dalam melakukan usahanya berusaha untuk meraih keuntungan sebesarbesarnya.

${ }^{4}$ Sutarto.Dasar-Dasar Kepemimpinan Administrasi, Cet. Ke 8, (Jakarta: Penerbit Gadjah Mada University Press GMUP, 2016), h. 25.

${ }^{5}$ Bisnis Muhammad saw.setelah menikah dengan Khadijah, seperi dideskripsikan dalam kunjungan Muhammad ke beberapa negara dan bentuk transaksi dalam Islam. Tercatat dalam sejarah, ketika Muhammad dalam usia 12 tahun ia sudah diajak untuk bisnis ke Syiria dan banyak pesan moral dalam menjalankan bisnis yang dirangkum dalam hadits. Lihat Muhammad, Etika Bisnis Islami, (Yogyakarta: UPP AMP YKPN, 2004), h. xv-xviii.

${ }^{6}$ Etika mencari harta dan membelanjakannya, strategi bisnis dan tujuannya, serta perilaku bisnis yang dianjurkan dan dilarang. Inimencerminkan etika bisnis Muhammad, menekankan pada teks-teks Alquran, seperti etika bisnis harus berlandaskan iman kepada Allah dan rasul-Nya, strategi bisnis harus sesuai dengan jalan Allah, dan tujuan bisnis untuk memperoleh keuntungan besar. Artinya etika bisnis terfokus pada kompilasi ayat-ayat Alquran dan hadits.Penekanan bisnis Islam pada pesan-pesan (nabi) Muhammad setelah menjadi Nabi (ba'd al bi'tsah). Lihat .Suyanto, Muhammad Business Strategy and Ethics, (Yogyakarta: Andi Offset, 2008), h. 169-218.

${ }^{7}$ Kemampuan mengelola bisnis tampak pada keberanian Nabi membawa dagangan Khadijah yang ditemani hanya seorang karyawan (Maisarah). Jika iatidak memiliki pengalaman dan kemampuan berdagang maka ia hanya akan menjadi pendamping Maisarah. Ia bertanggungjawab penuh atas semua dagangan milik Khadijah. Demikian juga halnya pada barang-barang dagangan yang ia bawa dari pasar ke pasar atau tempat-tempat festival perdagangan. Lihat M. Abdul Karim, History of the Muslim Thought and Civillization, terj. Tim Pustaka Book Publisher, Sejarah Pemikiran dan Peradaban, (Yogyakarta: Pustaka Book Publisher, 2007), h. 50dalam Muhammad Saifullah. Etika Bisnis Islami dalam Praktek Bisnis Rasulullah, dalam jurnal Walisongo, Volume 19, Nomor 1, Mei 2011, h. 134-140.

${ }^{8}$ Dalam Winardi, Motivasi dan Pemotivasian dalam ManajemenSumber Daya Manusia, (Jakarta: Raja Grasindo Persada, 2007), h. 1.

${ }^{9}$ Jarwanto, Pengantar Manajemen (3 IN 1), Mediatera, (Yogyakarta, 2015), h.92.

${ }^{10}$ IAI, 2009: 16. 2.

${ }^{11}$ A. Rahman Rais, SE salah seorang anggota panitia pendirian bank syariah PT. BPR Syariah Al-Washliyah dan juga Wakil Sekretaris PW AW SU pereode 2015-2020, wawancara pada hari Kamis, tanggal 24 Januari 2019 di rumah kediamannya.

${ }^{12}$ Lukman Hakim, Membangun Budaya Organisasi Unggul sebagai Upaya Meningkatkan Kinerja Karyawan di Era Kompetitif. BENEFIT dalam Jurnal Manajemen dan Bisnis, VOL. 15, No. 2, 2011, h. 148-158.

${ }^{13}$ Crow D. Leater dkk, Psikologi Pendidikan,(Yogyakarta: Nur Cahaya, 1989), h, 302-303.

${ }^{14}$ Abdul Rahman Shaleh dan Muhib Abdul Wahab, "Psikologi Suatu Pengantar (Dalam Perspektif Islam)", (Jakarta : Kencana, 2004), h. 264.

${ }^{15}$ Arikunto, (2005), Manajemen Penelitian, Jakarta: Rineka Cipta, , hal.51

${ }^{16}$ Dalam Rachmat Syafe'i, Fikih Mu'amalat, (Bandung: Pustaka Setia, 2004), h. 13.

${ }^{17}$ Al-“Alamah Syaikh Muhammad Nashiruddin Al-Ban.Shahih Ensiklopedi Hadits Qudsi, (Surabaya: Duta Ilmu. 2010), h. 143.

${ }^{18}$ Tim PB AW.Seperempat Abad Al Ja' yaul Wasliah, (Medan: PB AW, 1955), h. 19. 
${ }^{20} \mathrm{AD} / \mathrm{ART}$ AW.

${ }^{21}$ Muhammad Ridwan Ibrahim Lubis, Kepribadian Anggota \& Pengurus Al-Washliyah, (Jakarta: PP HIMMAH, 1994), 12.

${ }^{22}$ http://medan.tribunnews.com/2014/01/06/bpr-syariah-al-washliyah-harus-dukung-umkm. diaksaes pada tanggal 17 Desember 2018.

${ }^{23}$ Ahmad Zaki Az-Zahiri, Tinjauan tentang kontribusi ormas Al-Washliyah dalam pendidikan Islam di Indonesia, (Jakarta: FT. UIN Syarif Hidayatullah, 2015), h. 75

${ }^{24}$ Chalidjah Hasanuddin, Al Jamiatul Washliyah (1930-1942) Api dalam Sekam .(Bandung: Pustaka, 1993), h. 10.

${ }^{25}$ A. Rahman, SE wakil Sekretaris PW AW SU, bahwa Rumah Sakit/Klinik Al-Washliyah ini diutup, tidak beroperasi lagi sejak tahun 2004, wawancara di rumah peribadinya pada hari Kamis, 24 Januari 2019.

${ }^{26}$ H. Rauddin Purba, SPd.I, Ketua majeleis Amal Sosial Al-Washliyah Sumatera Urtara preode 2015-2020, wawancara pada tanggal. 22 Januari 2019.

${ }^{27}$ Pemberian nama gedung kuliah UMN Al-Washliyah dengan nama "Seych Muhammad Yunus" atas pertimbangan karena beliau semasa hidupnya adalah seorang ulama, mudir pada Maktab Islam Tapanuli (MIT) yaitu tempat para pendiri Al-Washliyah menimba ilmu, dimana belia pula yang telah memberi nama organisasi Al-Jam'iyatul Wahliyah atas permintaan para peserta rapat pembentukan Al-Washliyhah ketika itu.

${ }^{28}$ Artikel ; Dedi Iskandar Batubara adalahWakil Sekretaris PW Al Washliyah Sumatera Utara, Anggota Dewan Pendidikan Sumatera Utara, Sekretaris DPD KNPI Sumatera Utara, Mahasiswa Program Doktoral (S3) Studi Pembangunan FISIP USU, dan Anggota DPD RI Pemilu 2014-2019 Daerah Pemilihan Sumatera Utara. Lihat juga http://kabarwashliyah.com/2013/03/27/lembaga-pendidikan-al-washliyah-punya-siapa/, diakses pada tgl. 28-11-2018.

${ }^{29}$ Veithzal Rivai dan Dedy Mulyadi, Kepemimpinan dan Perilaku Organisasi, Edisi ketiga (Jakarta: Rajawali Pers, 2011), h. 3.

${ }^{30}$ Kemenag RI. Alquran dan Terjemahannya.(Surabaya: Mahkota, 1989), h.504.

${ }^{31}$ AD/ART Al-Washliyah

${ }^{32}$ Edy Purwo Saputro, Dosen Pascasarjana UniversitasMuhammadiyah Solo. Artikel: $N U$, Muhammadiyah, dan Penguatan Ekonomi;diupload padaMinggu, 26 November 2017. 14:22.

\footnotetext{
${ }^{35}$ Kementerian Agama RI, Alqurān dan Terjemahnya, .... h. 30.

${ }^{36}$ Asmuni dan Siti Mujiatun, Bisnis Syariah,... h. 12.

${ }^{37}$ Kementerian Agama RI, Alquran dan Terjemahnya, .... h. 16.

${ }^{38}$ Ibid, .....h. 662. ${ }^{39} \mathrm{I}$ bid, ....h. 622.

${ }^{40}$ Yazid bin abdul Qadir Jawaz. Syarah Arba 'in An-Nawawi, (Pustaka Imam Syafi'i. 2011),
} h. 7 .

${ }^{41}$ Al-'Alamah Syaikh Muhammad Nashiruddin Al-Ban.Shahih Ensiklopedi Hadits Qudsi, (Surabaya: Duta Ilmu. 2010), h. 143. 